\title{
EDITORIAL
}

\section{Blind Spots in International Law}

\author{
MACHIKO KANETAKE*
}

\begin{abstract}
This editorial aims to foster debate on the possible roles of implicit social cognition in international law. The editorial is in part inspired by a book entitled Blindspot: Hidden Biases of Good People, written by Banaji and Greenwald, researchers of social psychology. According to them, a large set of implicit biases reside in our minds, which may influence our behaviour towards ourselves and others. It is safe to argue that international judges, arbitrators, diplomats, domestic officials who apply international law, and international legal scholars are not immune from implicit bias. Within international legal scholarship, some relevant experiments have already been conducted in unveiling decision makers' intuitive and automatic thinking. While implicit bias is hard to identify and remedy, this editorial encourages international legal practitioners and scholars to diversify their own experiences and engage in the imagination of counter-stereotypes.
\end{abstract}

\section{INTRODUCTION}

A blind spot is an area of the visual field that is hidden from one's eye sight. Everyone has such a blind spot in the retina of each eye. By employing the concept as a metaphor, Mahzarin R. Banaji and Anthony G. Greenwald, researchers of social psychology, have written a book which made the findings of experimental psychology

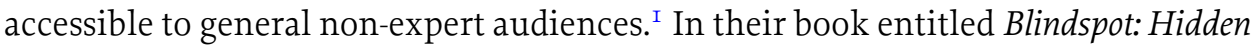
Biases of Good People (2013), ${ }^{2}$ Banaji and Greenwald account for a large set of hidden biases residing in one's mind. They are hidden or implicit in the sense that they escape from our mind's explicit cognitions. Ready-made solutions have yet to be compiled for reducing implicit biases which affect one's behaviour towards oneself and others. Merely acknowledging their existence does not always outsmart one's automatic categorical thinking. Instead, we must diversify our daily experiences and engage in the imagination of counter-stereotype realities.

* Senior Editor, Leiden Journal of International Law; Assistant Professor, School of Law, Utrecht University [m.kanetake@uu.nl].

I The fact that Banaji and Greenwald's book motivated me to engage with social psychology (i.e., another discipline) reminds me of the earlier editorial of this Journal, written by Cecily Rose, who suggested, in turn, that an international lawyer write a book accessible for a wider audience. See C. Rose, 'International Lawyers as Public Intellectuals and the Need for More Books', (2015) 28 Leiden Journal of International Law 393.

2 M.R. Banaji and A.G. Greenwald, Blindspot: Hidden Biases of Good People (2013). M.R. Banaji is a professor of psychology at Harvard University and A.G. Greenwald is a professor of psychology at the University of Washington. 
Is Blindspot relevant to international law? It is clear that institutional decisions pertaining to international law cannot be immune from the biases of individuals who are involved in decision-making. Yet the question is whether any such biases can be seen as normatively problematic. From a traditional point of view, one could argue that the possible influence of individuals' implicit bias is the least concern. International law builds on inter-state politics which already allow complex political preferences and strategies to be involved in different stages of its development. Should international law be embedded with inter-state politics, human actors' implicit social cognition therein may well be one of the least controversial players.

At the same time, however, there is no denying that, in certain circumstances, international law mandates, or at least strongly expects, a sense of impartiality on the part of those who apply international law. One such circumstance arises from international courts and tribunals where judges and arbitrators are mandated to apply law impartially to a given case. Another and more pressing set of circumstances is where international law prescribes the status and rights of individuals, as opposed to those of states. Human rights treaties provide a leading example in this regard. The implicit bias of those who apply international law can alter its effect on individuals concerned.

This editorial aims to trigger debate on junctures between implicit social cognition and international law and its scholarship. I believe that the possible roles of implicit bias should be more widely acknowledged and discussed, even if it is methodologically difficult to identify the extent to which implicit bias affects legal outcomes. It must be noted at the outset that the relevance of implicit bias is not the same as international law being inherently political. The findings of social psychology signal that there are even deeper roots of human behaviour which steer legal practices in a certain direction. This editorial does not intend to provide its own experimental findings regarding one's implicit bias in the practice of international law. My objectives here are to raise awareness of one's blind spots and to facilitate discussion on how they might affect international law and its scholarship.

\section{BLIND SPOT STUDIES IN SOCIAL PSYCHOLOGY}

In their book Blindspot: Hidden Biases of Good People, Banaji and Greenwald provide a glimpse of 'implicit' social cognition which influences people's attitudes towards themselves and others. Implicit social cognition is a field of research in social psychology, a broad discipline which studies the influence on people's thoughts, feelings and behaviours of the real or imagined presence of other people. ${ }^{3}$ According to the field of study, a belief can be explicit or implicit. One's belief is explicit if an actor is aware of the basis for action. By contrast, a belief is implicit in the sense that actors do not always have 'conscious, intentional control over the process of social perception, impression formation, and judgment that motivate their actions'. ${ }^{4}$

\footnotetext{
E. Aronson, T.D. Wilson and R.M. Akert, Social Psychology (8th edition, 20I4), 4.

4 A.G. Greenwald and L.H. Krieger, 'Implicit bias: Scientific foundations', (2006) 94 California Law Review 945 , at 946 .
} 
According to Banaji and Greenwald, much of the social cognition occurs in an implicit mode, as opposed to in a self-reportable and explicit manner. ${ }^{5}$ As one of the methods to measure implicit bias, Banaji and Greenwald explained a mechanism called the Implicit Association Test. ${ }^{6}$ It asks a participant to pair two concepts, such as 'male $=$ science' and 'female $=$ liberal arts', and then to reverse the pairing (i.e., 'male $=$ liberal arts' and 'female $=$ science'). The test measures how rapidly the participant can pair concepts into one group. Some people find it easier to pair 'male' with 'science' than matching 'female' with 'science'. I took one of the association tests on gender and science; the result ended up showing that I had 'a moderate automatic association for Male with Science and Female with Liberal Arts' - contrary to, I must add, my (explicit) beliefs. ${ }^{7}$

Implicit social cognition becomes problematic when it comes to a series of implicit biases, some of which have consequences that one's society no longer condones. Bias here denotes the association of attributes (such as, for instance, good, bad, skilled, unskilled, strong, weak, positive, negative, trustworthy, untrustworthy, rich, or poor) with social categories (such as, for example, those based on gender, race, nationality, religion, skin colour, age, clothing, voice, body languages, or narratives). A typical example is gender-based bias. Some people indeed have implicit 'female = family' and 'male = career' association. Such an implicit bias, even if the person is fully committed to gender equality, can influence not only one's attitudes towards others but also one's own behaviour. The bias may work, for example, as an unrecognized source of discomfort and restraint for women pursing their career. ${ }^{8}$ There are many other instances of implicit association, and it builds on the fact that our brain has 'stored years of past experiences that you cannot set aside'. ${ }^{9}$ Our brain makes and uses 'categories', and our living and swift reactions often rely on the use of such categories and automatic thinking.

While I, as a legal scholar, cannot assess the validity of the findings of social psychology, experimental psychology is said to have provided ample evidence that implicit social cognition influences one's thoughts, feelings, and actions about oneself and others. ${ }^{\text {IO }}$ Social psychology has accumulated studies on why discrimination and negative prejudice pervade many social settings even in a society or community which appears to be strongly multi-cultural and strives for diversity. A disturbing part of the findings is that individuals without any ill-conceived intention - or 'good' people - ended up being part of the 'systematic and selective patterns of decisionmaking that result in differential treatment'. ${ }^{\text {I }}$ It must be reiterated that implicit

5 A.G. Greenwald and M.R. Banaji, 'Implicit Social Cognition: Attitudes, Self-Esteem, and Stereotypes', (I995) IO2 Psychological Review 4.

6 Banaji and Greenwald, supra note 2, at 34-46; A.G. Greenwald, D.E. McGhee and J.L.K. Schwartz, 'Measuring Individual Differences in Implicit Cognition: The Implicit Association Test', (I 998) 74 Journal of Personality and Social Psychology 1464.

I took one of the Implicit Association Tests, available at implicit.harvard.edu/implicit/index.jsp.

Banaji and Greenwald, supra note 2, at 163.

Ibid., at 39.

K.A. Lane, J. Kang and M.R. Banaji, 'Implicit Social Cognition and Law', (2007) 3 Annual Review of Law and Social Science 427, at 427-3I.

II M.R. Banaji, R. Bhaskar and M. Brownstein, 'When bias is implicit, how might we think about repairing harm?', (2015) 6 Current Opinion in Psychology I83, at I 84. 
bias referred to here is not the same as one's political beliefs or political calculations. The studies suggest that people have implicit bias and may act on it without being aware of the basis for action, and, even against their explicit political or personal beliefs.

\section{Blind Spot STUdies in international LAW}

There is nothing novel in combining social psychology with legal studies. The psychology of law in general was notably proposed in the I930s by Jerome Frank, Thurman Arnold, and others as part of broader American legal realism. ${ }^{\text {I2 }}$ In response to the specific findings of social psychology on implicit biases, a number of studies have already been produced at the national level to analyze the implications of such biases in legal and social practices. Research has been conducted, for instance, on implicit bias in civil and criminal court proceedings, ${ }^{\mathrm{I3}}$ discrimination in employment, ${ }^{\mathrm{I} 4}$ and immigration proceedings in the US. ${ }^{\mathrm{I} 5}$ Experimental social psychology's findings on implicit forms of bias add yet another challenge to the idea of ordinary human behaviour based on intentional decision making, on which legal rationality has been built. ${ }^{16}$ Whether or not some of the findings of implicit bias should and can play a role in legal practices and reforms is a source of continued debate, both in academia and politics.

\section{I. Critical legal scholarship and behavioural economics}

Within international legal scholarship, reference to social psychology and implicit cognition remains rare. This scarcity is, presumably, due to the fact that international law traditionally deals with the conduct of a state as a unit, as opposed to the conduct of individuals. Having said this, there have been international legal studies which are proximate to, if not directly on, the analysis of implicit bias discussed in Blindspot. To begin with, critical legal studies in international law can be regarded as a relevant contribution. Historical and political assumptions unveiled by critical legal scholarship may inform and reinforce the biases of decision makers and legal scholars. Implicit bias can be one of many factors sustaining gendered legal languages highlighted by feminist approaches to international law ${ }^{17}$ or for justifying colonial legacies unpacked by Third World Approaches to International Law. ${ }^{\mathrm{I}}{ }^{\mathrm{T}}$ The 'structural

I2 E.g., J. Frank, Law and the Modern Mind (I930, 2017); T.W. Arnold, 'Law Enforcement. An Attempt at Social Dissection', (1932) 42 The Yale Law Journal I.

I3 E.g., J. Kang et al., 'Implicit Bias in the Courtroom', (20I2) 59 UCLA Law Review i I 24.

I4 E.g., L.H. Krieger and S.T. Fiske, 'Behavioral Realism in Employment Discrimination Law: Implicit Bias and Disparate Treatment’, (2006) 94 California Law Review 997.

I5 E.g., F.E. Marouf, 'Implicit Bias and Immigration Courts', (2010) 45 New England Law Review 4I 7.

i6 Banaji, Bhaskar and Brownstein, supra note I I, at I83.

${ }^{7}$ Among many studies see, e.g., H. Charlesworth and C.M. Chinkin, The Boundaries of International Law: A Feminist Analysis (2000).

I8 Among many studies see, e.g., A. Anghie, 'Finding the Peripheries: Sovereignty and Colonialism in Nineteenth-Century International Law', (I999) 40 Harvard International Law Journal I; A. Anghie and B.S. Chimni, 'Third World Approaches to International Law and Individual Repsonsibility in Internal Conflicts', (2003) 2 Chinese Journal of International Law 77. 
biases' of international institutions discussed by Martti Koskenniemi ${ }^{\text {I9 }}$ should also inform and strengthen the implicit bias of individuals involved. After all, individuals' bias is one manifestation of 'situationality' which, as Outi Korhonen describes, 'locates an individual in time and space, history, tradition and physical reality'. ${ }^{20}$

At the same time, the implications of the findings of social psychology on implicit bias are not the same as the 'political' projects unveiled by critical legal studies in international law. Social and political ideologies affect individuals' bias, but the central message of Blindspot is that people behave in a certain biased way, even if they become aware of social and political assumptions that surround them and even if they try to act in a politically neutral, un-biased, and impartial manner.

Beyond critical legal scholarship, Anne van Aaken and Tomer Broude, among others, developed the analyses of international law from the angles of behavioural economics and cognitive psychology. ${ }^{2 \mathrm{I}}$ A behavioural approach to international law, including international economic law, casts doubt on the assumption that human behaviour is perfectly rational and utility-maximizing with defined self-interest. Instead, the approach starts with the recognition that humans' cognitive capacities lead to decisions that appear erroneous or irrational. ${ }^{22}$ Behavioural approaches, which primarily developed to analyze the behaviour of individuals, should work as an analytical angle for international law as well. This is because international law is ultimately implemented by individuals, such as immigration officers, customs officials, legal advisors, and soldiers. Also, individuals are addressees or beneficiaries under, for instance, international criminal law, international human rights law, and international humanitarian law. ${ }^{23}$ Although, in general, behavioural approaches to international law do not directly address implicit social cognition and implicit bias, part of the irrationality of those involved can be explained by the automatic association of certain attributes to social categories.

\subsection{Inside the minds of judges and arbitrators in dispute settlement}

Moving to more context-specific analyses, there has been a group of studies which identify certain biases on the part of judges and arbitrators in international courts and tribunals. As Thomas Frank noted in I966, it is 'common knowledge' that we all have biases and that 'subjective' and 'socially conditioned' attitudes of the

I9 E.g., M. Koskenniemi, 'The Politics of International Law-20 Years Later', (2009) 20 European Journal of International Law 7.

20 O. Korhonen, 'New International Law: Silence, Defence or Deliverance?', (I996) 7 European Journal of International Law I, at 7.

2 A. van Aaken, 'Behavioral International Law and Economics', (20I4) 55 Harvard International Law Journal 42 I; T. Broude, 'Behavioral International Law', (2014) I63 University of Pennsylvania Law Review Io99; A. van Aaken and Tomer Broude, 'Behavioral Economic Analysis of International Law', in E. Kontorovich and F. Parisi (eds.), Economic Analysis of International Law (2016), 249. Needless to say, there are many other scholars who have analyzed international law from a behavioural economics perspective: see, e.g., A. Steinbach, 'The Trend towards Non-Consensualism in Public International Law: A (Behavioural) Law and Economics Perspective', (2016) 27 European Journal of International Law 643.

22 Broude, 'Behavioral International Law', supra note 2 I, at I I I 2-20; van Aaken, 'Behavioral International Law and Economics', supra note $2 \mathrm{I}$, at 424-35.

23 Broude, 'Behavioral International Law', supra note 21, at i i 29-30. 
decision maker play a role. ${ }^{24}$ Judges surely carry their own prior predispositions, and the requirement of impartiality by no means asks any judge to discard them. ${ }^{25}$ Nevertheless, steps can still be taken in order to reduce the influence of bias, should it be substantiated empirically. ${ }^{26}$ For that matter, 2 I years ago, this Journal published Martin Kuijer's analysis of voting behaviour, ${ }^{27}$ in which national bias among the judges of the International Court of Justice (ICJ) was proved to be 'more than a hypothesis'. ${ }^{28}$ Eric Posner and Miguel de Figueiredo's data published in 2005 further suggested that the judges at the ICJ voted, not only for their home states (90\% of the time), but also in favour of states whose economic level or political system is similar to that of the judges' own states. ${ }^{29}$ Implicit social cognition should be part of many complex factors in debating why biases, if any, exist, in what sense, and whether any such biases could be seen as legitimate against the functions to be fulfilled by the ICJ.

More recently, intriguing experiments have been conducted, which help us understand tendencies in the decision making of international arbitrators. Susan D. Franck et al. conducted a psychological experiment involving 262 international (commercial or investment) arbitrators. ${ }^{30}$ The participants resolved mock disputes and took the Cognitive Reflection Test that contained a set of questions with which to assess whether arbitrators could override their intuitive yet incorrect judgments. The experiment led to the observation that international arbitrators often render 'intuitive and impressionistic decisions' as opposed to 'fully rational and deliberative decisions'. ${ }^{3 \mathrm{I}}$

On another experimental front, Sergio Puig and Anton Strezhnev carried out an analysis with a group of investor-state arbitrators. ${ }^{32}$ Based on 257 fully completed survey results, Puig and Strezhnev identified evidence of arbitrators' bias towards economically weaker states when it comes to the reimbursement of those states' legal costs. According to their experiment, arbitrators gave 'more favourable judgments to claimants from middle-income states compared to those from high-income states', and 'low-income respondent states received additional compensation compared to middle-income respondent states'.33 Puig and Strezhnev's experiment also found

24 T.M. Franck, 'Some Psychological Factors in International Third-Party Decision-Making', (I966) I9 Stanford Law Review I 2 I 7, at I 247.

25 See G.I. Hernandez, 'Impartiality, Bias, and the International Court of Justice', (20I2) I Cambridge Journal of International and Comparative Law $\mathrm{I} 83$.

26 See Franck, supra note 24, I 2 I 7-47 (making a series of suggestions to reduce biases).

27 M. Kuijer, 'Voting Behaviour and National Bias in the European Court of Human Rights and the International Court of Justice', (I997) Io Leiden Journal of International Law 49.

28 Ibid., at 66.

29 E.A. Posner and M.F.P. de Figueiredo, 'Is the International Court of Justice Biased?', (2005) 34 Journal of Legal Studies 599.

$30 \quad$ S.D. Franck et al., 'Inside the Arbitrator's Mind', (2017) 66 Emory Law Journal I I 5.

3I Ibid., at I I66.

32 S. Puig and A. Strezhnev, 'The David Effect and ISDS', (2017) 28 European Journal of International Law 73 I.

33 Ibid., at 733 . 
evidence of 'affiliation bias' in favour of the arbitrators' appointing party, not only with regard to decisions on costs, but also more substantive questions. ${ }^{34}$ If arbitrators who participated in the experiments did their best to remain unbiased, the identified types of bias may have been something more automatic and intuitive.

\subsection{Inside the minds of those determining individuals' statuses}

Apart from the context of dispute settlement, there is another set of circumstances in which implicit bias should play a role and, more importantly, has immediate consequences for individuals. International law prescribes the status, rights and obligations of individuals (as opposed to states), especially under international human rights law, refugee law, international humanitarian law, and international criminal law. Even if these sets of principles and rules of international law have been intertwined with inter-state politics, the principle and rules would be, either directly or through their domestic implementing legislation, applied to individuals and determine their human rights, refugee status, protective status, or even individual criminal responsibility. Implicit social cognition and implicit bias should therefore be part of the discussion if international lawyers aim at comprehending how international law is applied by governmental officials, soldiers, prosecutors, and judges to individuals concerned.

Many questions can be raised on the possible relevance of implicit bias to international legal practice and the domestic application of international law. Has implicit bias, such as those based on race or gender, been one of the factors which undermine the effective implementation of international human rights treaties, and if so, in what sense? What should and can the UN's human rights bodies do about this? How about the assessment of asylum seekers and their fear of persecution? Under international humanitarian law, what would be the implications of implicit bias based on, for instance, race, nationality, religion, and gender, on the treatment of the prisoners of war and detainees during and in the aftermath of armed conflicts? How about the assessment of proportionality in military operations? Luke A. Whittemore points out that the normative principle of proportionality in jus in bello has developed based on the rational choice of commanders and fails to take into account cognitive biases which may lead to inconsistent decisions on the part of commanders as human beings. 35

Implicit bias has been discussed in legal literature especially in the field of nondiscrimination. Implicit social bias, if pervasive, can be a tricky source of discriminatory behaviours. This does not mean that international law, or law in general, ought to step in for the regulation of such an unseen and rather obscure factor. Uncertainties persist with regard to the role of implicit bias in one's actual behaviour, and, at any rate, it is hard for legal mechanisms to regulate something which is

34 S. Puig and A. Strezhnev, 'Affiliation Bias in Arbitration: An Experimental Approach', (2017) 46 The Journal of Legal Studies 37 I.

35 L.A. Whittemore, 'Proportionality Decision Making in Targeting: Heuristics, Cognitive Biases, and the Law', (2016) 7 Harvard National Security Journal 577. 
not immediately recognizable. At the same time, this does not mean that implicit bias is irrelevant to the achievement of the equal treatment of individuals in legal practices. Educational training may be necessary, not only for judges, but also for other governmental officials, so that they can be aware of the possible influence of automatic decisions and be cautious about their intuitive judgment.

\section{Blind spots in JOURnAl SUbMission AND REVIEW PROCESSES}

Apart from the practice of international law, does implicit bias have any relevance to the process to review journal submissions? Blind peer review is motivated, at least in part, by the foreseeable influence of bias on a reviewer's decision. Any researchers carry their own preferences and biases based on their own prior experiences. As long as the peer review process is blind, namely, if a reviewer cannot see any identifying information of the author, it should be possible to minimize the influence of categorical thinking solely on the basis of the author's names, institutions, and previous publications without assessing the merits of the article itself. This Journal adopts a double-blind peer review, whereby neither reviewers nor authors are informed of their respective identity.

In view of the reasons why blind review is introduced, it is not surprising that the questions of bias have been raised with regard to those law journals which do not yet adopt a blind review process. For instance, most of the student-reviewed law journals in the US do not incorporate blind review, despite the fact that, according to one survey, 72.6 per cent of I,089 law professors prefer the entire law review selection process to be blind. ${ }^{36}$ It is common to attach a CV when you submit an article to USbased student reviewed journals. Not surprisingly, authors' institutional affiliations and previous publications influence selection processes, especially in top ranked law reviews. ${ }^{37}$ Also, apart from these self-reported factors that influence selection, one has to take into account that some of the high-ranking US law reviews receive the largest number of submissions. This puts law review editors under extreme time pressure. Making decisions under time pressure increases the likelihood of automatic thinking playing a role in the selection of manuscripts. ${ }^{38}$

Finally, implicit social cognition may also influence one's behaviour regarding whether or not to submit one's manuscripts to a particular journal or publisher. According to Banaji and Greenwald, the authors of Blindspot, if a person belongs to historically-disadvantaged groups, the association of certain unfavourable attributes to those groups can be self-undermining, in that they work as an implicit source of restraint. ${ }^{39}$ For instance, the person may not even think of submitting his or her

36 R.A. Wise et al., 'Do Law Reviews Need Reform: A Survey of Law Professors, Student Editors, Attorneys, and Judges', (2013) 59 Loyola Law Review I, at 55-6. See also J. Gingerich, 'A Call for Blind Review: Student Edited Law Reviews and Bias', (2009) 59 Journal of Legal Education 269.

37 L.M. Christensen and J.A. Oseid, 'Navigating the Law Review Article Selection Process: An Empirical Study of Those with All the Power - Student Editors', (2007) 59 South Carolina Law Review I75, at I88-93.

38 M.J. Higdon, 'Beyond the Metatheoretical: Implicit Bias in Law Review Article Selection', (20I6) 5I Wake Forest L. Rev. 339, at 342-3. See also Marouf, supra note I5, at 43 I.

39 Banaji and Greenwald, supra note 2, at 163. 
articles to some of the leading journals of international law due to some kind of self-restraint. I believe that it is worth asking if you have had such an experience in the past. A journal's editorial board members - including this Journal - also have an important role to play in actively soliciting paper submissions from a variety of scholars and practitioners.

\section{Conclusion: Remedying Blind Spots}

This editorial is aimed at raising awareness of implicit bias which may influence the shapes of international law and its scholarship. The issue is pertinent, not only because the institutional decisions of states and international organizations are rendered, after all, by a group of human beings. The debate is pertinent also because international legal scholars have a share in constructing the principles, rules, and practices of international law. Needless to say, explicit or disguised forms of bias persist in many corners of our societies to the extent that some of the biases contravene non-discrimination under various human rights treaties. The psychological findings on implicit bias by no means discount the need for countering intentional forms of discrimination in various corners of our society.

While it is methodologically hard to measure any implicit bias existing in the practices of international law and its domestic application, it is also not readily possible to separate international legal practices, or its scholarship, from the blind spots of those individuals who are involved in the production of, and understanding about, international law. Awareness of blind spots bears importance especially because many fields of international law prescribe the status and rights of individuals, as opposed to those of state institutions.

What can we do then to outsmart implicit bias which may influence one's behaviour towards others and ourselves? The mere awareness of one's hidden biases does not seem to help us eradicate them. ${ }^{40}$ One activity which proved successful in modifying category-based attributes is to do some simple exercises to imagine alternative realities. One such exercise referred to by Banaji and Greenwald in their book is to create a computer screensaver with a series of images which represent counter-stereotypes. ${ }^{4 \mathrm{I}}$ For instance, I have included in my screensaver a photo taken at Kabul University in Afghanistan in the late I950s or early I960s, in which both women and men were taking a university-level biology class. ${ }^{42}$ To me, this was one of the counter-stereotyping images which I hoped would diversify my own implicit attributes about the country, its people, educational systems, and historical dynamics.

Overall, we can only be attentive to our hidden biases and start recognizing their possible takeover of our thinking and behaviour by exposing ourselves to

\footnotetext{
Ibid., at I49.

Ibid., at I5I-2.

'Biology class during the late I950s or early I960s', Wikipedia Commons, available at commons.wikimedia.org/wiki/File\%3AI950s_Afghanistan_-_Biology_class\%2C_Kabul_University.jpg; Published in 'Once Upon a Time in Afghanistan' by Mohammad Qayoumi, Foreign Policy (27 May 2010).
} 
new writings, languages, platforms, images, people, and communities in an openminded manner without the fear of being challenged. This editorial, which I have the privilege of writing, cannot also be immune to my own blind spots. I can only appreciate any future feedback and comments which allow me to be cognizant of my own blind spots and help international legal scholarship become more open, dynamic, and inclusive. 